\title{
Development and optimization of flaked breakfast cereal processing parameters and formulation, incorporated with banana pulp and peel, using response surface methodology
}

\author{
1, *Tay, H.X., ${ }^{2}$ Kuan, C.H., ${ }^{3}$ Chong, G.H., ${ }^{4}$ New, C.Y. and ${ }^{3}$ Son, R. \\ ${ }^{1}$ Faculty of Science, Universiti Tunku Abdul Rahman, 31900, Kampar, Perak, Malaysia \\ ${ }^{2}$ Department of Food Science with Nutrition, Faculty of Applied Sciences, UCSI University Kuala Lumpur, \\ No. 1, Jalan Menara Gading, UCSI Heights, 56000 Cheras, Kuala Lumpur, Malaysia \\ ${ }^{3}$ Faculty of Food Science and Technology, Universiti Putra Malaysia, 43400 Serdang, Selangor, Malaysia \\ ${ }^{4}$ Go Plus Services Sdn Bhd, 97A, Jalan BP 6/3, Bandar Bukit Puchong, 47120 Puchong, Selangor, Malaysia
}

\begin{abstract}
Article history:
Received: 6 August 2020

Received in revised form: 4

October 2020

Accepted: 17 November 2020

Available Online: 21

February 2021

\section{Keywords:}

Ready-to-eat breakfast cereal, Fracturability,

Yellowness,

Optimization,

Response surface

methodology (RSM)
\end{abstract}

\section{DOI:}

https://doi.org/10.26656/fr.2017.5(2).486

\begin{abstract}
Breakfast cereal plays an important role in a balanced diet. In Malaysia, tons of highly nutritious banana peels, overripe, oversupplied and rejected bananas end up in food waste, as a result of high production and consumption of banana. Thus, this study aimed to produce flaked breakfast cereal with banana pulp, banana peel and cornmeal through oven -baking. Baking temperature, baking time and volume of banana pulp and peel mixture were optimized by using response surface methodology (RSM) to achieve desired fracturability and yellowness. Through this study, fracturability $\left(\mathrm{R}^{2}=0.98, \mathrm{P} \leq 0.05\right)$ and yellowness $\left(R^{2}=0.99, P \leq 0.05\right)$ were found to be significantly related to the processing parameters and formulation of the flakes. The optimum processing parameters and formula obtained from this study were the baking temperature of $129.5^{\circ} \mathrm{C}$, baking time of 15 mins and volume of banana pulp and peel mixture of $140 \mathrm{~g}$. Besides, a sensory evaluation was conducted and compared among the optimized flakes and commercial corn flakes. Based on the results, there was a significant difference $(\mathrm{P} \leq 0.05)$ in aroma, appearance and taste but no significant difference $(\mathrm{P}>0.05)$ in mouthfeel and overall acceptability between both types of flakes. It was recommended that the shelf-life study of the optimized flakes could be done for future study.
\end{abstract}

\section{Introduction}

Breakfast is the first meal of the day that is eaten in the period of two to three hours after waking up. As the meal that breaks the fast after the longest period of a person's sleep, it consists of food and beverage from at least one food group stated in MyPlate (O'Neil et al., 2014). Failure to consume breakfast links to serious health implication. It was reported that there is a $27 \%$ increase in risk for coronary heart disease and lowered cognitive performance in men who failed to consume breakfast (Cahill et al., 2013; Spence, 2017).

In the current market, breakfast cereal products can be divided into cooked cereals and cold breakfast cereal. Cornflakes are considered a ready-to-eat cold breakfast cereal (Priebe and McMonagle, 2016). In 2016, ready-toeat cereal had occupied more than $86 \%$ of breakfast cereal market share (Technavio, 2017).

Banana ranked fourth as the most important food constitute in the world, after rice, corn and milk (Nik Yusuf et al., 2016). In Malaysia, banana is one of the most produced and exported local fruit crops (Kayat et al., 2016). With the consumption of $10 \mathrm{~kg}$ per capita, banana is rated to be highly consumed in Malaysia (DOSM, 2018). Popular varieties of banana available in Malaysia are Pisang Mas, Pisang Rastali and Pisang Berangan (Mohamad Roff et al., 2012). Besides cheap, banana is high in carbohydrate, vitamins and minerals, which fulfils the criteria for calibre breakfast (Pareek, 2016; Sidhu and Zafar, 2018). Furthermore, it was identified that banana peel has high antioxidants and total phenolic content (Ibrahim et al., 2017).

On each day, 15,000 tons of food waste is generated in Malaysia (Abd Razak, 2017). In Malaysia, $46.82 \%$ of municipal solid waste was made up of food waste (Johari et al., 2014). Fruits and vegetables had contributed 50\% to the food wastage (FAO, 2011). In Malaysia, with high production and consumption of banana, banana peels, 
overripe, oversupplied and rejected bananas end up contributing to the food waste in Malaysia. In addition, banana fruit also has a high turnover rate in the market as it overripe very fast (Kjørstad, 2018). It takes only 11 days for the banana to be fully matured, under room temperature (Lima et al., 2014).

Therefore, the idea to incorporate banana pulp and peel in the production of flaked breakfast cereal was ignited, not only to produce a nutritious breakfast but also to tackle Malaysia's food waste scenario. This study aimed to develop and find the optimum processing parameters and formula for the production of flaked breakfast cereal incorporated with banana pulp and peel.

\section{Materials and methods}

\subsection{Preparation of raw materials}

Banana (Musa acuminata Colla (AA Group) 'Sucrier', also known locally as Pisang Mas) was purchased from the local wet market in Kampar, Perak, Malaysia (Lim, 2012). Banana used was in maturity stage seven, where its peel was yellow with brown spots observed (National Horticulture Board, 2011).

Banana, with the peel intact, was weighed according to the factor level stated in Table 1. It was rinsed with water, cut into slices of $1 \mathrm{~cm}$ width and then soaked in $1 \%(\mathrm{v} / \mathrm{v})$ citric acid solution for 10 mins. After that, banana slices were rinsed with distilled water. Cornmeal (Siti Bakery Ingredients House, Malaysia), sugar (Malayan Sugar Manufacturing Co. Bhd., Malaysia), banana flavouring (Siti Bakery Ingredients House, Malaysia), and salt (Seng Hin Brothers Enterprises, Malaysia) were weighed according to Table 2. All ingredients were placed into a kitchen blender (MX-

Table 1. Box-Behnken design with different combinations of factors

\begin{tabular}{cccc}
\hline \multirow{2}{*}{$\begin{array}{c}\text { Run } \\
\text { No. }\end{array}$} & \begin{tabular}{c} 
Baking \\
\cline { 2 - 4 }
\end{tabular} & $\begin{array}{c}\text { Baking Time } \\
(\mathrm{min})\end{array}$ & $\begin{array}{c}\text { Volume of banana pulp } \\
\text { and peel mixture }(\mathrm{g})\end{array}$ \\
\hline 1 & $0(125)$ & $-1(15)$ & $-1(140)$ \\
2 & $0(125)$ & $1(25)$ & $1(180)$ \\
3 & $-1(100)$ & $1(25)$ & $0(160)$ \\
4 & $1(150)$ & $-1(15)$ & $0(160)$ \\
5 & $1(150)$ & $0(20)$ & $-1(140)$ \\
6 & $0(125)$ & $0(20)$ & $0(160)$ \\
7 & $-1(100)$ & $0(20)$ & $-1(140)$ \\
8 & $0(125)$ & $-1(15)$ & $1(180)$ \\
9 & $-1(100)$ & $0(20)$ & $1(180)$ \\
10 & $0(125)$ & $1(25)$ & $-1(140)$ \\
11 & $1(150)$ & $1(25)$ & $0(160)$ \\
12 & $0(125)$ & $0(20)$ & $0(160)$ \\
13 & $1(150)$ & $0(20)$ & $1(180)$ \\
14 & $0(125)$ & $0(20)$ & $0(160)$ \\
15 & $-1(100)$ & $-1(15)$ & $0(160)$ \\
\hline
\end{tabular}

GM1011, Panasonic, Malaysia) and blended until even mixing was achieved.

Table 2. Formulation of flaked breakfast cereal incorporated with banana pulp and peel

\begin{tabular}{cc}
\hline Ingredient & Amount \\
\hline Banana pulp and peel mixture & Variable $*$ \\
Cornmeal & $30.0 \mathrm{~g}$ \\
Sugar & $7.88 \mathrm{~g}$ \\
Banana flavouring & $0.70 \mathrm{~g}$ \\
Salt & $0.53 \mathrm{~g}$ \\
Water & $45 \mathrm{~mL}$ \\
\hline
\end{tabular}

* Amount varied according to experimental design as shown in Table 1.

\subsection{Baking process}

A $55 \mathrm{~mL}$ blended batter was spread evenly on a baking sheet, with the area of $20 \mathrm{~cm} \times 20 \mathrm{~cm}$. The batter was dried in a preheated oven (FC 110 E, Roller Grill, France) at $125^{\circ} \mathrm{C}$ for 20 mins. After 20 mins, the batter was removed from the oven and cooled for 5 mins. The batter was then torn into flakes, with an area of approximately $3 \mathrm{~cm} \times 3 \mathrm{~cm}$. Flakes were baked in the oven at time and temperature according to the designated factor level as shown in Table 1. The end product was left to cool before subjected to any sensory acceptance test.

\subsection{Texture analysis (fracturability)}

Texture characteristic (fracturability) of the flakes was measured by using a texture analyser (TA.XT Plus, Stable Micro Systems, United Kingdom) with Exponent Lite software through compression test. Before loading it with the sample, the instrument was calibrated with a 5 $\mathrm{kg}$ load cell with $25 \mathrm{~mm}$ return distance, $20 \mathrm{~mm} / \mathrm{s}$ return speed and $5 \mathrm{~g}$ contact force. The instrument setting for fracturability analysis of flakes was summarized in Table 3. Fracturability was defined as the force from the first significant peak observed in the texture analyser graph (Sahin and Sumnu, 2007). Samples were analysed in triplicate and mean value was calculated.

Table 3. Instrument setting for fracturability analysis

\begin{tabular}{cc}
\hline Texture Analyzer Setting & Description \\
\hline Option & Measure force in compression \\
Load cell & $25 \mathrm{~kg}$ \\
Probe & Crisp fracture rig (HDP/CFS) \\
Pre-test speed & $1.0 \mathrm{~mm} / \mathrm{s}$ \\
Test speed & $1.0 \mathrm{~mm} / \mathrm{s}$ \\
Post-test speed & $10.0 \mathrm{~mm} / \mathrm{s}$ \\
Distance & $3 \mathrm{~mm}$ \\
Trigger type & Auto $-5 \mathrm{~g}$ \\
Tare mode & Auto \\
Data acquisition rate & $500 \mathrm{pps}$
\end{tabular}




\subsection{Colour analysis (yellowness)}

A chromameter (CR-410, Konica Minolta, Tokyo, Japan) was used to determine the yellowness of the flakes by measuring $b^{*}$ value. Colour analysis was done with the use of Hunter lab colour parameters, where higher $b^{*}$ value corresponded more yellow (Aramouni and Deschenes, 2015). Samples were analysed in triplicate and mean value was calculated.

\subsection{Experiment design and data analysis}

The Box-Behnken design in RSM was employed in this study to obtain optimum formulation and processing parameters, where three independent variables with three levels were involved in this design. The three independent variables (factors) were baking temperature $\left(100^{\circ} \mathrm{C}, 125^{\circ} \mathrm{C}\right.$ and $\left.150^{\circ} \mathrm{C}\right)$, baking time $(15 \mathrm{mins}, 20$ mins and 25 mins) and volume of banana pulp and peel mixture $(140 \mathrm{~g}, 160 \mathrm{~g}$, and $180 \mathrm{~g})$. The dependent variables (responses) studied in this experiment were texture (fracturability) and colour (yellowness). The Box -Behnken design, as shown in Table 1, was made up of 15 runs, with three centre points included to examine the reproducibility of this method (Yewale and Chattopadhyay, 2013).

All data obtained from this experimental design was analysed and interpreted with JMP Statistical Discovery Software from SAS (version 13.0.0). Analysis of variance (ANOVA) and regression analysis was conducted based on the data obtained. As this study involves the Box-Behnken design with three factors and three levels, the experimental data were fitted into a second-order polynomial regression model as shown in the equation below to describe the relationship between factors and response:

$\mathrm{Y}=\beta_{0}+\beta_{1} \mathrm{X}_{1}+\beta_{2} \mathrm{X}_{2}+\beta_{3} \mathrm{X}_{3}+\beta_{12} \mathrm{X}_{1} \mathrm{X}_{2}+\beta_{13} \mathrm{X}_{1} \mathrm{X}_{3}+\beta_{23} \mathrm{X}_{2} \mathrm{X}_{3}+\beta_{11} \mathrm{X}_{1}^{2}+\beta_{22} \mathrm{X}_{2}^{2}+\beta_{33} \mathrm{X}_{3}^{2}$

where $\mathrm{Y}$ was the predicted response; $\beta_{0}$ was the model constant; $\beta_{1}, \beta_{2}$ and $\beta_{3}$ were the linear coefficient; $\beta_{12,} \beta_{13}$ and $\beta_{23}$ were the cross-product coefficient; $\beta_{11}, \beta_{22}$ and $\beta_{33}$ were the quadratic coefficient. The $R^{2}$ value of the second-order model was expressed to determine the quality of fit of this model (Pasma et al., 2013). Effect of interaction among independent variables and responses were then analysed through response surface plots.

\subsection{Optimization and verification}

The optimum formulation and processing parameters for flaked breakfast cereal incorporated with banana pulp and peel were determined with the use of JMP software. It was done under the following constraints: fracturability between $175 \mathrm{~g}$ and $185 \mathrm{~g}$; maximum yellowness. A verification experiment was conducted to verify the adequacy of the model applied in predicting the optimum formulation and processing parameters (Charunuch et al., 2011). The significant difference ( $\mathrm{P} \leq$ $0.05)$ between the responses and the predicted values was tested.

\subsection{Sensory evaluation}

Sensory evaluation was conducted to evaluate the sensory acceptance of the optimized flaked banana breakfast cereal with Kellogg's corn flakes, a commercially available corn flakes. The attributes of aroma, appearance, taste, mouthfeel and overall acceptability were evaluated with 9-point hedonic scaling (Lawless and Heymann, 2010). This evaluation involved 90 untrained panellists. Samples were presented with codes of random three-digit numbers to prevent bias. Drinking water was provided for the panellist to rinse their mouth before tasting each sample. The significant difference $(\mathrm{P} \leq 0.05)$ of the results of the sensory evaluation were analysed statistically with $\mathrm{T}$-test using JMP software.

\section{Results and discussion}

The experimental result for each response was tabulated in Table 4 and analysed with regression analysis ANOVA (Table 5). It was shown that both fracturability and yellowness were highly significant at $(\mathrm{P} \leq 0.05)$. Thus, the usage of fracturability and yellowness to generate polynomial regression models were verified.

\subsection{Fracturability}

The second-order polynomial regression model that defined the relationship between fracturability and all factors is shown in the equation below:

$\mathrm{Y}_{1}($ Fracturability $)=157.97+46.61 \mathrm{~A}+2.64 \mathrm{~B}-22.40 \mathrm{C}$ $+7.43 \mathrm{AB}-9.75 \mathrm{AC}-5.85 \mathrm{BC}+5.90 \mathrm{~A}^{2}-4.80 \mathrm{~B}^{2}-$ $3.98 \mathrm{C}^{2}$

Where A refers to baking temperature, $\mathrm{B}$ refers to the baking time and $\mathrm{C}$ refers to the volume of banana pulp and peel mixture. Based on the equation, first-order $\mathrm{A}$ and $\mathrm{B}$ terms, the interaction term of $\mathrm{AB}$ term and quadratic $\mathrm{A}$ and $\mathrm{C}$ terms had a linear relationship with fracturability. Based on the F-values, it was observed that baking temperature and volume of banana pulp and peel mixture had a significant effect $(\mathrm{P} \leq 0.05)$ on fracturability.

As shown in Figure 1, the highest fracturability was observed when both baking temperature and baking time was at the highest level. According to Figure 2, fracturability increased when baking temperature 
Table 4. Experimental result for fracturability and yellowness

\begin{tabular}{cccccc}
\hline \multirow{2}{*}{ Run } & \multicolumn{3}{c}{ Factor } & \multicolumn{2}{c}{ Response } \\
\cline { 2 - 6 } & A & B & C & Fracturability $(\mathrm{g})$ & Yellowness \\
\hline 1 & 0 & -1 & -1 & 166.4 & 7.22 \\
2 & 0 & 1 & 1 & 136.2 & 7.24 \\
3 & -1 & 1 & 0 & 110.8 & 8.79 \\
4 & 1 & -1 & 0 & 192.5 & 1.46 \\
5 & 1 & 0 & -1 & 254.4 & 1.33 \\
6 & 0 & 0 & 0 & 157.1 & 4.87 \\
7 & -1 & 0 & -1 & 140.6 & 5.4 \\
8 & 0 & -1 & 1 & 147.8 & 3.09 \\
9 & -1 & 0 & 1 & 100.8 & 8.17 \\
10 & 0 & 1 & -1 & 178.2 & 2.38 \\
11 & 1 & 1 & 0 & 217.8 & 0.4 \\
12 & 0 & 0 & 0 & 157.5 & 4.81 \\
13 & 1 & 0 & 1 & 175.6 & 0.81 \\
14 & 0 & 0 & 0 & 159.3 & 4.89 \\
15 & -1 & -1 & 0 & 115.2 & 6.93 \\
\hline \multicolumn{3}{c}{ Mean } & & 160.7 & 4.52 \\
\hline
\end{tabular}

Table 5. Regression coefficient and ANOVA of various responses

\begin{tabular}{ccc}
\hline Parameters & Fracturability & Yellowness \\
\hline \multicolumn{3}{c}{ Regression Coefficient } \\
\hline Intercept & $157.97^{*}$ & $4.86^{*}$ \\
$\beta_{\mathrm{A}}$ & $46.61^{*}$ & $-3.16^{*}$ \\
$\beta_{\mathrm{B}}$ & 2.64 & 0.01 \\
$\beta_{\mathrm{C}}$ & $-22.40^{*}$ & 0.37 \\
$\beta_{\mathrm{AB}}$ & 7.43 & $-0.73^{*}$ \\
$\beta_{\mathrm{AC}}$ & -9.75 & $-0.82^{*}$ \\
$\beta_{\mathrm{BC}}$ & -5.85 & $2.25^{*}$ \\
$\beta_{\mathrm{AA}}$ & 5.9 & $-0.76^{*}$ \\
$\beta_{\mathrm{BB}}$ & -4.8 & 0.3 \\
$\beta_{\mathrm{CC}}$ & 3.98 & -0.17 \\
\hline \multicolumn{3}{c}{ ANOVA } \\
\hline$R^{2}$ & 0.98 & 0.99 \\
Model F-value & $26.06^{*}$ & $46.20^{*}$
\end{tabular}

*Significant $(\mathrm{p} \leq 0.05), \mathrm{A}=$ Baking temperature, $\mathrm{B}=$ Baking time, $\mathrm{C}=$ Volume of banana pulp and peel mixture

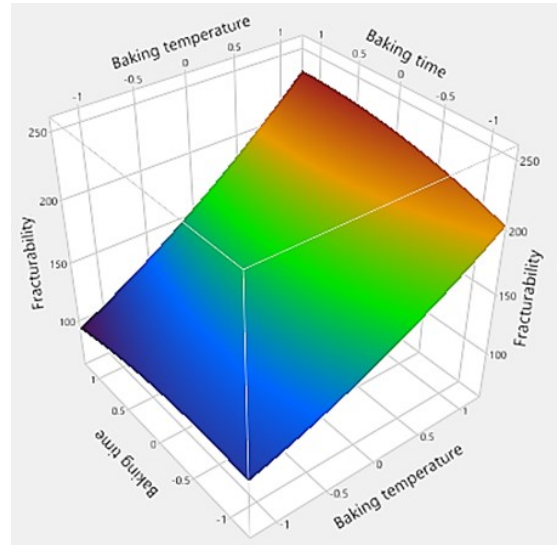

Figure 1. Response surface plot for the effect of interaction between baking temperature and baking time on fracturability

increased and the volume of banana pulp and peel mixture decreased. Highest fracturability was observed when the baking temperature was at the highest level and volume of banana pulp and peel mixture was at the lowest level (Figure 2). Figure 3 shows that fracturability increased when baking time increased and the volume of banana pulp and peel decreased.

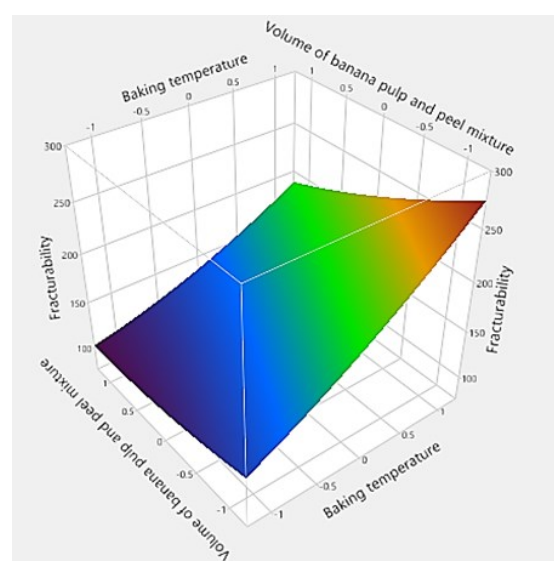

Figure 2. Response surface plot for the effect of interaction between baking temperature and volume of banana pulp and peel mixture on fracturability

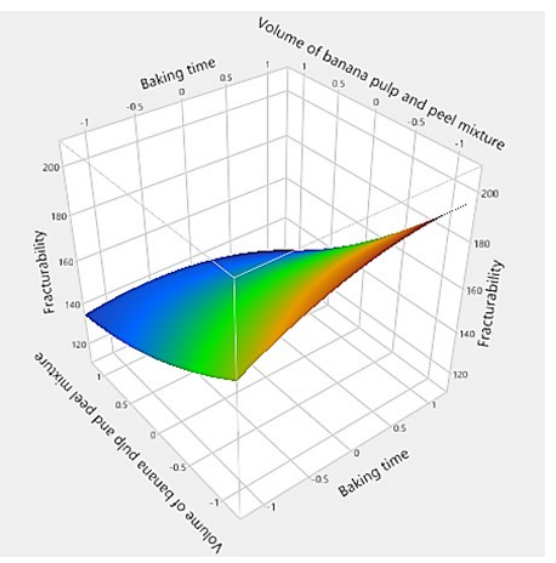

Figure 3. Response surface plot for the effect of interaction between baking time and volume of banana pulp and peel mixture on fracturability

Fracturability was proven to be highly significant $(\mathrm{P} \leq 0.05)$ through ANOVA. This reflected the importance of fracturability as the hallmark feature for the texture of flaked breakfast cereal since it can affect the palatability and sensory quality of food products and therefore affecting consumer acceptance on this breakfast cereal (Meghwal and Goswami, 2012; Onwulata et al., 2013). The adequacy of the regression model for fracturability was proven with high $\mathrm{R}^{2}$ value of 0.98 . This value indicated that the data obtained in the experiment fits the model, where $98 \%$ variability in this response can be predicted by the model (Pasma et al., 2013; Hamilton et al., 2015).

It was found that fracturability is governed by moisture content (Tunick et al., 2013). Baking temperature portrayed a significant positive effect on fracturability, which conformed with the study by Jaiswal (2017). This was largely due to the linear relationship between moisture loss and baking temperature. As oven temperature increased, kinetic energy in water molecules increased, hydrogen bonds 
between water molecules broke faster, thus, the molecules were released into surrounding air at a higher rate (Nagata et al., 2015).

Besides that, the volume of banana pulp and peel was also an influencing factor on fracturabiliy. According to the regression analysis (Table 5), it had a significant negative effect $(\mathrm{P} \leq 0.05)$ on fracturability. There were no current studies that discussed the interaction between the addition of fruit and breakfast cereal fracturabilty. Nonetheless, based on Figure 2 and Figure 3, the fracturability of flakes increased when the volume of banana pulp and peel decreased. This was due to the high moisture content from the fresh banana. Previous studies showed that banana pulp has a moisture content of $74.7 \pm 1.3 \%$ and the banana peel has a moisture content of $6.70 \pm 2.22 \%$ (Nguyen and Price, 2007; Anhwange et al., 2009). Hence, with a higher volume of fresh banana pulp and peel incorporated into the formulation, flakes with higher moisture content were yielded and subsequently reduced the fracturability.

\subsection{Yellowness}

The second-order polynomial regression model that described the relationship between yellowness and all factors is shown in the equation below:

$\mathrm{Y}_{2}$ (Yellowness) $=4.86-3.16 \mathrm{~A}+0.01 \mathrm{~B}+0.37 \mathrm{C}-$ $0.73 \mathrm{AB}-0.82 \mathrm{AC}+2.25 \mathrm{BC}-0.76 \mathrm{~A}^{2}+0.30 \mathrm{~B}^{2}-$ $0.17 \mathrm{C}^{2}$

where A refers to baking temperature, $\mathrm{B}$ refers to the baking time and $\mathrm{C}$ refers to the volume of banana pulp and peel mixture. According to this equation, first-order $\mathrm{B}$ and $\mathrm{C}$ terms, the interaction term of $\mathrm{BC}$ term and quadratic $B$ term had a linear relationship with yellowness. Based on the F-values, baking temperature, the interaction effect between baking temperature and baking time, the interaction effect between baking temperature and volume of banana pulp and peel mixture, the interaction effect between baking time and volume of banana pulp and peel mixture and interaction effect between baking temperatures had significant effects $(P \leq 0.05)$ on yellowness.

Based on Figure 4, yellowness increased when the baking temperature was decreased and baking time was increased. Highest yellowness was observed when the baking temperature was set at the lowest level and baking time was set at the highest level. Yellowness increased when baking temperature decreased and the volume of banana pulp and peel mixture increased (Figure 5). According to Figure 6, yellowness increased when both baking time and volume of banana pulp and peel mixture were increased simultaneously or decreased simultaneously.
Colour is one of the most important quality attributes for a breakfast cereal as it affects product quality and sensory properties and eventually influences consumer acceptance (Mahony, 2001). The importance of colour was reflected in this study, where yellowness was reported to be highly significant $(\mathrm{P} \leq 0.05)$ based on ANOVA. The adequacy of the regression model for yellowness was proven with the $\mathrm{R}^{2}$ value of 0.99 , where $99 \%$ variability in this response can be predicted by the model (Pasma et al., 2013; Hamilton et al., 2015).

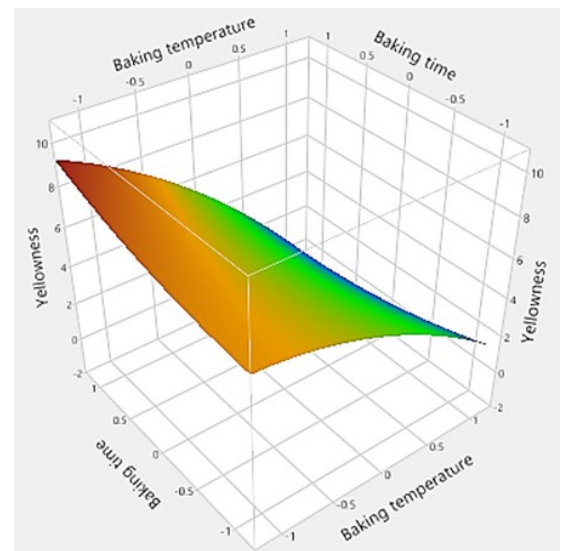

Figure 4. Response surface plot for the effect of interaction between baking temperature and baking time on yellowness

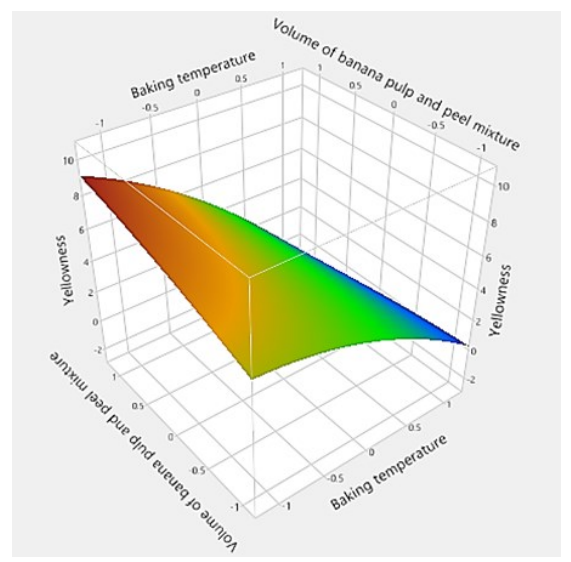

Figure 5. Response surface plot for the effect of interaction between baking temperature and volume of banana pulp and peel mixture on yellowness

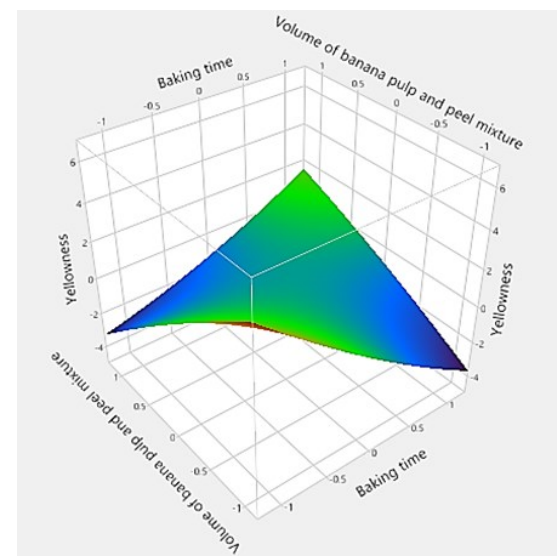

Figure 6. Response surface plot for the effect of interaction between baking time and volume of banana pulp and peel mixture on yellowness 
Among the three factors involved, only baking temperature exerted a significant effect $(\mathrm{P} \leq 0.05)$ on yellowness. The baking temperature had a significant negative relationship with yellowness. Yellowness in the flakes was contributed by the carotenoids available in the main ingredients such as cornmeal, banana pulp and banana peel. These ingredients are rich in carotenoids, such as lutein and $\beta$-carotene, which allow them to have yellow colour by default (Khoo et al., 2011; Fu et al., 2018). The degradation of carotenoid is highly dependent on temperature. Carotenoid undergoes cis-isomerization under high temperature, causing the decrease in transcarotene and increase in cis-carotene, which has lower absorption wavelength of $330-350 \mathrm{~nm}$; while the wavelength of visible light ranges from $400-780 \mathrm{~nm}$ (Pénicaud et al., 2011; Ogherohwo et al., 2015). Consequently, colour from carotenoid is less visible and thus, causing a decrease of yellowness. Besides, carotenoid also degrades through oxidation when exposed to high temperature, where the double bonds in the molecule are oxidized by oxygen and aldehydes and ketones are formed (Ramel et al., 2013). Thus, through these degradation mechanisms, yellowness in the flakes decreased when the baking temperature increased, showing coherence to the studies done by Kaur et al. (2014) and Jirasatid et al. (2018).

\subsection{Optimization}

In this study, the desired fracturability and yellowness were achieved with the baking temperature of $129.5^{\circ} \mathrm{C}$, baking time of 15 mins and volume of banana pulp and peel mixture of $140 \mathrm{~g}$. The optimum results were verified experimentally. There was no significant difference $(\mathrm{P}>0.05)$ between the measured fracturability and yellowness with the predicted values.

\subsection{Sensory evaluation}

The mean sensory scores from ninety panellists for optimized flakes and Kellogg's corn flakes were illustrated in Table 6. The aroma of optimized flakes scored significantly higher $(\mathrm{P} \leq 0.05)$. In addition to banana pulp, the aroma might be contributed by the banana flavouring added. The addition of it was encouraged by the findings of the positive influence of olfactory properties on product marketing, consumer behaviour and consumer satisfaction (Ouyang et al., 2017).
The sensory score of the taste of optimized flakes was significantly higher $(\mathrm{P} \leq 0.05)$ than Kellogg's corn flakes. This can be due to the sweeter taste in the optimized flakes compared to Kellogg's corn flakes, which was contributed by the natural sugar from banana pulp added. Sweetness acts as a stimulator of eating and provides pleasure responses, thus, giving a better taste in food products (Sclafani, 2007).

On the other hand, the sensory score of the appearance of optimized flakes was significantly lower $(\mathrm{P} \leq 0.05)$ than Kellogg's corn flakes. This can be due to the dark yellow colour of optimized flakes, which might be caused by the Maillard reaction of sugar and enzymatic browning of polyphenol oxidase in banana (Arpita et al., 2010; Tamanna and Mahmood, 2015). It was reported that consumer generally dislikes dark yellow due to its association with faeces, vomit or rotting food (Schloss and Palmer, 2011). Therefore, optimized flakes had a lower score for appearance.

Mouthfeel is defined as the tactile aspects of food during consumption, which contributes to consumer preference and acceptance (Stokes et al., 2013). There was no significant difference $(\mathrm{P}>0.05)$ for the mouthfeel of both types of samples. However, mouthfeel scoring was slightly inclined towards Kellogg's corn flakes.

In addition, there was also no significant difference $(\mathrm{P}>0.05)$ between the overall acceptability of both samples. Nonetheless, optimized flakes had slightly higher overall acceptance than Kellogg's corn flakes. This could be a piece of evidence for the market potential of this product.

\subsection{Product impact}

With the development of flaked banana breakfast cereal, the amount of food waste in Malaysia can be reduced through converting overripe, oversupply and rejected ugly produce into a nutritious and marketcompetent product with extended shelf life. Beneficial compounds available in banana peel were also able to be fully utilized, instead of treated as waste.

According to a survey conducted by DOSM (2017), as of 2016, the total number of household in Malaysia was 6.9 million with an average household size of 4.1 people. It was reported that the consumption trend of breakfast cereal in Malaysia was inclined towards Indian

Table 6. Mean sensory scores for optimized flakes and Kellogg's corn flakes

\begin{tabular}{cccccc}
\hline Sample & Aroma & Appearance & Taste & Mouthfeel & Overall Acceptability \\
\hline Optimized flakes & $7.10 \pm 1.14^{\mathrm{a}}$ & $6.11 \pm 1.40^{\mathrm{a}}$ & $7.00 \pm 1.46^{\mathrm{a}}$ & $6.64 \pm 1.46^{\mathrm{a}}$ & $7.00 \pm 1.19^{\mathrm{a}}$ \\
Kellogg's corn flakes & $6.37 \pm 1.33^{\mathrm{b}}$ & $7.09 \pm 1.11^{\mathrm{b}}$ & $6.37 \pm 1.28^{\mathrm{b}}$ & $6.68 \pm 1.39^{\mathrm{a}}$ & $6.71 \pm 1.29^{\mathrm{a}}$ \\
\hline
\end{tabular}

Values are expressed as mean \pm standard deviation. Values with different superscript within the column are significantly different $(\mathrm{p} \leq 0.05)$. 
ethnicity, higher income, higher education level and residence in the urban area (Mohd Nasir et al., 2017). Assuming that only $1 \%$ of household in Malaysia can afford daily consumption of this product. With a conservative assumption of one serving ( $30 \mathrm{~g}$ ) of banana cereal flakes consumed per individual per day, the daily demand would be $8,487 \mathrm{~kg}$ flakes. Banana made up approximately $62 \%$ of the formulation for one serving. Therefore, $5,261.94 \mathrm{~kg}$ of overripe, oversupply or rejected banana would be utilized every day, instead of contributing to food waste.

\section{Conclusion}

Through this study, it was found that baking temperature exerted a significant positive effect on the fracturability of flakes, due to the increase in the rate of moisture loss when baking temperature increase. Furthermore, the volume of banana pulp and peel had a significant negative relationship with fracturability because a higher amount of fresh banana in the formulation contributes to higher moisture content. On the other hand, yellowness of flakes was significantly affected by baking temperature as a result of the degradation of carotenoids at high temperature. The study highlighted the optimum processing parameters to be the baking temperature of $129.5^{\circ} \mathrm{C}$ with a baking time of 15 mins and volume of banana pulp and peel mixture of $140 \mathrm{~g}$. The overall sensory acceptance of the optimized flakes was higher than commercially available corn flakes, which could be the evidence for the market potential of this product. This product aids in reducing Malaysia food waste by converting banana peel and overripe banana pulp into wholesome and saleable breakfast cereal. It was recommended that shelf-life testing of the optimized flakes could be done for future study. Besides, an analysis of the antioxidant and potassium content in the flakes could also be conducted.

\section{Conflict of interest}

The authors declare no conflict of interest.

\section{Acknowledgements}

This research did not receive any specific grant from funding agencies in the public, commercial, or not-forprofit sectors.

\section{References}

Abd Razak, S. (2017). Household food waste prevention in Malaysia: An issue processes model perspective. Florida, USA: University of South Florida, MSc Thesis.

Anhwange, B., Ugye, J. and Nyiatagher, T. (2009).
Chemical composition of Musa sepientum (banana) peels. Electronic Journal of Environmental, Agricultural and Food Chemistry, 8(6), 437-442.

Aramouni, F. and Deschenes, K. (2015). Methods for developing new food products. Lancaster: DEStech Publications Inc.

Arpita, S., Subroto, D., Pinaki, B. and Bidyut, B. (2010). Inhibition of polyphenol oxidase in banana, apple and mushroom by using different anti-browning agents under different conditions. International Journal of Chemical Sciences, 8(5), S550-S558.

Cahill, L., Chiuve, S., Mekary, R., Jensen, M., Flint, A., Hu, F. and Rimm, E. (2013). Prospective study of breakfast eating and incident coronary heart disease in a cohort of male US health professionals. Circulation, 128(4), 337-343. https:// doi.org/10.1161/CIRCULATIONAHA.113.001474.

Charunuch, C., Limsangouan, N., Prasert, W. and Butsuwan, P. (2011). Optimization of extrusion conditions for functional ready-to-eat breakfast cereal. Food Science and Technology Research, 17 (5), 415-422. https://doi.org/10.3136/fstr.17.415

DOSM (Department of Statistics Malaysia). (2017). Report of household income and basic amenities survey 2016. Retrieved from DOSM website: https://www.dosm.gov.my/v1/index.php? $\mathrm{r}=$ column/ pdfPrev\&id=RUZ5REwveU1ra1hGL21JWVIPRmU 2Zz09.

DOSM (Department of Statistics Malaysia). (2018). Supply and utilization accounts selected agricultural commodities, Malaysia 2013-2017. Retrieved from DOSM website: https:// www.dosm.gov.my/v1/index.php?r=column/ pdfPrev\&id=ZE12RXM2SDM1eGRxRXR3bU0xRT hrUT09.

FAO (Food and Agriculture Organization of the United Nations). (2011). Global food losses and food waste. Retrieved from FAO website: http://www.fao.org/3/a -i2697e.pdf.

Fu, X., Cheng, S., Liao, Y., Huang, B., Du, B., Zeng, W., Jiang, Y., Duan, X. and Yang, Z. (2018). Comparative analysis of pigments in red and yellow banana fruit. Food Chemistry, 239, 1009-1018. https://doi.org/10.1016/j.foodchem.2017.07.046.

Hamilton, D., Ghert, M. and Simpson, A. (2015). Interpreting regression models in clinical outcome studies. Bone and Joint Research, 4(9), 152-153. https://doi.org/10.1302/2046-3758.49.2000571

Ibrahim, U., Kamarrudin, N., Suzihaque, M. and Abd Hashib, S. (2017). Local fruit wastes as a potential source of natural antioxidant: An overview. IOP 
Conference Series: Materials Science and Engineering, 206, $12040 . \quad \mathrm{https}: / /$ doi.org/10.1088/1757-899X/206/1/012040.

Jaiswal, A. (2017). Food processing technologies: Impact on product attributes. Boca Raton: CRC Press. https://doi.org/10.1201/9781315372365

Jirasatid, S., Chaikham, P. and Nopharatana, M. (2018). Thermal degradation kinetics of total carotenoids and antioxidant activity in banana-pumpkin puree using Arrhenius, Eyring-Polanyi and Ball models. International Food Research Journal, 25(5), 1912-1919. http://www.ifrj.upm.edu.my/25\%20 (05)\%202018/(20).pdf.

Johari, A., Alkali, H., Hashim, H., Ahmed, S. and Mat, R. (2014). Municipal solid waste management and potential revenue from recycling in Malaysia. Modern Applied Science, 8(4), 42. https:// doi.org/10.5539/mas.v8n4p37.

Kaur, G., Rehal, J., Singh, A., Singh, B. and Kaur, A. (2014). Optimization of extrusion parameters for development of ready-to-eat breakfast cereal using RSM. Asian Journal of Dairy and Food Research, 33(2), 77. https://doi.org/10.5958/09760563.2014.00580.6.

Kayat, F., Mohammad Amizi, A., Idris, A., Ibrahim, M., Soon, J.M., Ahmad Yusuf, M., Wong, K. and Zulariff, A. (2016). Study of the intention of banana growers in improving the production in Jeli, Kelantan. Asia Pacific Journal of Advanced Business and Social Studies, 2(2), 350-358.

Khoo, H., Prasad, K., Kong, K., Jiang, Y. and Ismail, A. (2011). Carotenoids and their isomers: Color pigments in fruits and vegetables. Molecules, 16, $1710-1738$ molecules 16021710 .

Kjørstad, E. (2018). These are the fruits and vegetables we waste the most. Retrieved on September 30, 2018 from Science Nordic website: http:// sciencenordic.com/these-are-fruits-and-vegetableswe-waste-most Accessed 30 September 2018.

Lawless, H. and Heymann, H. (2010). Sensory evaluation of food. 2nd ed. New York: Springer. https://doi.org/10.1007/978-1-4419-6488-5

Lim, T.K. (2012). Edible medicinal and non-medicinal plants. Dordrecht: Springer. https:// doi.org/10.1007/978-94-007-1764-0

Lima, O., Souza, E., Amorim, E. and Pereira, M. (2014). Ripening and shelf life of 'BRS Caipira' banana fruit stored under room temperature or refrigeration. Ciência Rural, 44(4), 734-739. https:// doi.org/10.1590/S0103-84782014000400027

Mahony, A. (2001). Effect of color on the odor, flavor, and acceptance properties of foods and beverages. Kansas, USA: Kansas State University, MSc Thesis. https://core.ac.uk/download/pdf/5172889.pdf.

Meghwal, M. and Goswami, T. (2012). Effect of moisture content on the physical and textural properties of fenugreek seed. Food, 6(1), 14-21. https://www.researchgate.net/

publication/272295320 Effect of Moisture Content on_the_Physical_and_Textural_Properties_of_Fenu greek Seed.

Mohamad Roff, M.N., Tengku Abdul Malik, T.M. and Sharif, H. (2012). Challenges to banana production in Malaysia: A threat to food security. The Planter, Kuala Lumpur, 88(1030), 13-21. https:// www.researchgate.net/

publication/313800642 Challenges to banana prod uction_in_Malaysia_A_threat_to_food_security\#: :t ext $=$ The $\% 20$ global $\% 20$ banana $\% 20$ production $\%$ 20is,the\%20Cavendish\%20plantations\%20in\% 201990s.

Mohd Nasir, M.T., Nurliyana, A.R., Norimah, A.K., Jan Mohamed, H.J.B., Tan, S.Y., Appukutty, M., Hopkins, S., Thielecke, F., Ong, M.K., Ning, C. and Tee, E.S. (2017). Consumption of ready-to-eat cereals (RTEC) among Malaysian children and association with socio-demographics and nutrient intakes - findings from the MyBreakfast study. Food and Nutrition Research, 61(1), 1304692. https:// doi.org/10.1080/16546628.2017.1304692

Nagata, Y., Usui, K. and Bonn, M. (2015). Molecular mechanism of water evaporation. Physical Review Letters, 115, 236102. https://doi.org/10.1103/ PhysRevLett.115.236102.

National Horticulture Board (NHB) (2011). Technical standards and protocol for the fruit ripening chamber in India. Retrieved from NHB website: http:// nhb.gov.in/guideline/cs4.pdf.

Nguyen, M. and Price, W. (2007). Air-drying of banana: influence of experimental parameters, slab thickness, banana maturity and harvesting season. Journal of Food Engineering, 79(1), 200-207. https:// doi.org/10.1016/j.jfoodeng.2006.01.063.

Nik Yusuf, N., Rosly, E., Mohamed, M., Abu Bakar, B., Yusoff, M., Sulaiman, M. and Ahmad, M. (2016). Waste banana peel and its potentialization in agricultural applications: Morphology overview. Materials Science Forum, 840, 394-398. https://doi.org/10.4028/www.scientific.net/ MSF.840.394.

Ogherohwo, E., Barnabas, B. and Alafiatayo, A. (2015). Investigating the wavelength of light and its effect on the performance of a solar photovoltaic module. International Journal of Innovative 
Research in Computer Science and Technology, 3 (4), 61-65.

O'Neil, C., Byrd-Bredbenner, C., Hayes, D., Jana, L., Klinger, S. and Stephenson-Martin, S. (2014). The role of breakfast in health: Definition and criteria for a quality breakfast. Journal of the Academy of Nutrition and Dietetics, 114(12), S8-S26. https:// doi.org/10.1016/j.jand.2014.08.022.

Onwulata, C., Pimentel, M., Thomas, A., Phillips, J., Tunick, M., Mukhopadhyay, S., Sheen, S., Liu, C., Latona, N. and Cooke, P. (2013). Instrumental textural perception of food and comparative biomaterials. International Journal of Food Properties, 16(4), 928-948. https:// doi.org/10.1080/10942912.2011.570469.

Ouyang, Y., Behnke, C., Almanza, B. and Ghiselli, R. (2017). The influence of food aromas on restaurant consumer emotions, perceptions, and purchases. Journal of Hospitality Marketing and Management, 27(4), 405-423. https:// doi.org/10.1080/19368623.2017.1374225.

Pareek, S. (2016). Nutritional and biochemical composition of banana (Musa spp.) cultivars. In Preedy, V.R. and Simmonds, M.S.J. (Ed.). Nutritional Composition of Fruit Cultivars, p. 49-81. USA: Academic Press. https://doi.org/10.1016/B978 -0-12-408117-8.00003-9.

Pasma, S., Daik, R., Maskat, M. and Hassan, O. (2013). Application of Box-Behnken design in optimization of glucose production from oil palm empty fruit bunch cellulose. International Journal of Polymer Science, 2013, $104502 . \quad \mathrm{https}: / /$ doi.org/10.1155/2013/104502.

Pénicaud, C., Achir, N., Dhuique-Mayer, C., Dornier, M. and Bohuon, P. (2011). Degradation of $\beta$-carotene during fruit and vegetable processing or storage: Reaction mechanisms and kinetic aspects: A review. Fruits, 66(6), 417-440. https:// doi.org/10.1051/fruits/2011058.

Priebe, M. and McMonagle, J. (2016). Effects of readyto-eat-cereals on key nutritional and health outcomes: A systematic review. PLoS ONE, 11(10), e0164931. https://doi.org/10.1371/ journal.pone.0164931.

Ramel, F., Mialoundama, A. and Havaux, M. (2013). Nonenzymic carotenoid oxidation and photooxidative stress signalling in plants. Journal of Experimental Botany, 64(3), 799-805. https:// doi.org/10.1093/jxb/ers223.

Sahin, S. and Sumnu, S. (2007). Physical properties of foods. New York: Springer.

Schloss, K. and Palmer, S. (2011). Aesthetic response to color combinations: Preference, harmony, and similarity. Attention, Perception, and Psychophysics, 73(2), 551-571. https://doi.org/10.3758/s13414-0100027-0.

Sclafani, A. (2007). Sweet taste signalling in the gut. Proceedings of the National Academy of Sciences, 104(38), 14887-14888. https:// doi.org/10.1073/pnas.0707410104.

Sidhu, J. and Zafar, T. (2018). Bioactive compounds in banana fruits and their health benefits. Food Quality and Safety, 2(4), 183-188. https://doi.org/10.1093/ fqsafe/fyy019.

Spence, C. (2017). Breakfast: The most important meal of the day. International Journal of Gastronomy and Food Science, 8, 1-6. https://doi.org/10.1016/ j.ijgfs.2017.01.003.

Stokes, J., Boehm, M. and Baier, S. (2013). Oral processing, texture and mouthfeel: From rheology to tribology and beyond. Current Opinion in Colloid and Interface Science, 18(4), 349-359. https:// doi.org/10.1016/j.cocis.2013.04.010.

Tamanna, N. and Mahmood, N. (2015). Food processing and Maillard reaction products: Effect on human health and nutrition. International Journal of Food Science, 2015, 526762. https:// doi.org/10.1155/2015/526762.

Technavio. (2017). Global breakfast cereals market 2017 -2021. London, England: Technavio.

Tunick, M., Onwulata, C., Thomas, A., Phillips, J., Mukhopadhyay, S., Sheen, S., Liu, C., Latona, N., Pimentel, M. and Cooke, P. (2013). Critical evaluation of crispy and crunchy textures: A review. International Journal of Food Properties, 16 (5), 949-963. https:// doi.org/10.1080/10942912.2011.573116.

Yewale, C. and Chattopadhyay, P. (2013). High temperature short time air puffed ready-to-eat (RTE) tapioca-peanut snack: Process parameters optimization. International Journal of Food Engineering, 10(1), 191-201. https:// doi.org/10.1515/ijfe-2012-0007. 